\title{
Efficiency of agrobusiness development in agriculture
}

\author{
Abduraim Toshboev ${ }^{1, *}$, Dilshod Mamadiyarov ${ }^{1}$, Shokhrukh Baymuradov ${ }^{2}$, Uchkun Alimov \\ ${ }^{3}$, Sanjarbek Iskandarov ${ }^{4}$ \\ ${ }^{1}$ Tashkent State agrarian University, Universitetskaya str., 2, 100140, Kibray district, Tashkent \\ region, Uzbekistan \\ ${ }^{2}$ Tashkent State University of Economics, 49 Uzbekistan street, 100003, Tashkent, Uzbekistan \\ ${ }^{3}$ Tashkent institute of irrigation and agricultural mechanization engineers, 39, Kari Niyazov \\ street, 100000, Tashkent, Uzbekistan \\ ${ }^{4}$ Andijan Institute of Agriculture and Agro Technologies, 1 Oliygokh street, Kuygan-yor town, \\ 170600, Andijan district, Andijan region, Uzbekistan
}

\begin{abstract}
The aim of the study is to study global economic problems that focus on the cultivation of agricultural products and the provision of food for consumption by the population. The article examines the future sustainable development of food production in our country, at the level of state policy and requires new approaches and reforms. The main guiding methods chosen in this study include: method of analysis, method of comparison, method of statistics, method of grouping, method of planning and forecasting. The object of the article is the agricultural state of the Republic of Uzbekistan, since the Republic of Uzbekistan is an agroindustrial state, where more than $49.5 \%$ of the population lives in rural areas, and almost half of the entire employed population works in the agricultural sector. The subject of the research is the agricultural sector of the Gallaorol region of the Republic of Uzbekistan. As a result of the study, it was revealed that in the Gallaorol region, where the research was carried out, the industry was not developed, and the income of the population was formed only due to agricultural products. In the conclusion, new opportunities for increasing the socio-economic well-being of the population are proposed through the formation of agribusiness in the region and appropriate recommendations are given.
\end{abstract}

\section{Introduction}

Today, in the process of reforming the agrarian sector of the economy, a number of problems arise that hinder the growth of the economic efficiency of enterprises in the industry. Therefore, at the current stage of radical changes in the economy, in the context of modernization of the economy and the economy based on private property, the integration of small and large industries in rural areas, i.e. the development of their integration and cooperation is an objective necessity. In this context, in the conditions of free choice of the

\footnotetext{
*Corresponding author: indira91@inbox.ru
} 
form of land ownership, it is important to increase the specialization and efficiency of farms, management systems of divisions, inter-farm and intra-farm relations.[1]

In this case, commercial settlements, commodity-money relations will have to be observed in all production and service structures. In rural areas, it is necessary to create conditions not only for small business and private entrepreneurship, but also for all producers to earn a living at a level that ensures their livelihood and normal production, but also allows for expanded reproduction.

Based on the above considerations, it is advisable to pay special attention to the following aspects of the development and running of farms - a promising form of management:

- Global agricultural experience shows that farms have a complex advantage. Because the main criterion for development is interest. This is the interest of the farm and a strong desire to achieve a high end result;

- use of available production resources, ownership change in relations, dominance of the land over the farmer, development of a sense of attitude towards the goods produced by the farmer himself, securing property, is directly related to the growth of entrepreneurship;

-agriculture is fully Autonomous production, self-sufficient, doing business on the basis of self-financing, relations with market participants should be organized on the basis of partnership, through the commodity market and on the basis of mutual benefit. In a market economy, agricultural enterprises are a complex, economically dynamic system that consists of organizational and relatively independent common production units. [2,3]

Purpose of research. Mechanisms for the formation and development of agribusiness in agriculture are the development of scientific proposals and practical recommendations aimed at improving management.

Subject of research these are the organizational, economic and legal relations of improving the management of mechanisms for the formation and development of agribusiness. The object of the study was the agricultural sector of the gallyaral district of the Jizzakh region.

Novelty of scientific research:

- The socio-economic foundations of improving the management of mechanisms for the formation and development of agribusiness in the context of structural changes in agriculture have been studied. At the same time, an independent approach to the concepts of agribusiness and entrepreneurship was developed as applied to the scientific literature.

- The socio-economic forms of small business and private entrepreneurship in agriculture are identified and their logical and structural classification is developed.

- The features and stages of development of small business and entrepreneurship in the economy and agriculture of the republic are revealed.

- Recommendations for strengthening state support for the development of small business and private entrepreneurship in rural areas have been developed.

- The basic principles for the implementation of the concept of accelerated development of farmers, dekhkan farms and cooperatives, which form the basis of small business in agriculture.

Theoretical and practical significance of the study. Theoretical conclusions and practical recommendations summarized in the research process can be used in the development of a strategic concept for improving the management of mechanisms for the formation and development of agribusiness in the Gallaorol region and in agriculture, in particular, in the programming and organizational activities of higher educational institutions and scientific institutions.[4,5] 


\section{Methodology}

According to our research, Table 1 shows the programs for the development of agricultural land for 2015-2020, and in the region in 2015, from 48482 hectares of arable land by 2020 will decrease to 40775 hectares or 7707 hectares. This was reduced for the population on the reduced land and for the construction of commercial facilities.

Table 1. Indicators of the area of the main agricultural crops in the Gallaoral region for 2017-2021

(Source: Department of Agriculture of the Gallaorol region).

\begin{tabular}{|c|c|c|c|c|c|c|c|c|c|}
\hline № & $\begin{array}{l}\text { Agricultura } \\
\text { I crops }\end{array}$ & $\begin{array}{c}\text { Unit of } \\
\text { measurem } \\
\text { ent }\end{array}$ & $\begin{array}{c}2015 \\
\text { reportin } \\
\text { g year }\end{array}$ & $\begin{array}{c}2016 \\
\text { estimat } \\
\text { e }\end{array}$ & 2017 & 2018 & 2019 & 2020 & 2021 \\
\hline \multirow[t]{2}{*}{1} & Cotton & ha & & & & & & & \\
\hline & percentage & $\%$ & 0.0 & 0.0 & 0.0 & 0.0 & 0.0 & 0.0 & 0.0 \\
\hline \multirow[t]{2}{*}{2} & Cereals & ha & 39452 & 32500 & $\begin{array}{c}32 \\
000\end{array}$ & $\begin{array}{c}31 \\
300\end{array}$ & $\begin{array}{c}30 \\
\mathbf{5 0 0}\end{array}$ & $\begin{array}{c}30 \\
200\end{array}$ & $\begin{array}{c}30 \\
200\end{array}$ \\
\hline & percentage & $\%$ & 81.4 & 77.6 & 76.8 & 75.9 & 74.8 & 74.1 & 73.5 \\
\hline \multirow[t]{2}{*}{3} & Potato & ha & 427 & 283 & 297 & 312 & 328 & 344 & 361 \\
\hline & percentage & $\%$ & 0.9 & 0.7 & 0.7 & 0.8 & 0.8 & 0.8 & 0.9 \\
\hline \multirow[t]{2}{*}{4} & Vegetables & ha & 1135 & 1376 & $\begin{array}{c}1 \\
445\end{array}$ & $\begin{array}{c}1 \\
517\end{array}$ & $\begin{array}{c}1 \\
593\end{array}$ & $\begin{array}{c}1 \\
673\end{array}$ & 1756 \\
\hline & percentage & $\%$ & 2.3 & 3.3 & 3.5 & 3.7 & 3.9 & 4.1 & 4.3 \\
\hline \multirow[t]{2}{*}{5} & Melon & ha & 236 & 218 & 229 & 240 & 252 & 265 & 278 \\
\hline & percentage & $\%$ & 0.5 & 0.5 & 0.5 & 0.6 & 0.6 & 0.6 & 0.7 \\
\hline \multirow[t]{2}{*}{6} & Fruit & ha & 1878 & 1931 & $\begin{array}{c}2 \\
028\end{array}$ & $\begin{array}{c}2 \\
129\end{array}$ & $\begin{array}{c}2 \\
235\end{array}$ & $\begin{array}{c}2 \\
347\end{array}$ & 2464 \\
\hline & percentage & $\%$ & 3.9 & 4.6 & 4.9 & 5.2 & 5.5 & 5.8 & 6.0 \\
\hline \multirow[t]{2}{*}{7} & $\begin{array}{l}\text { Fodder } \\
\text { crop }\end{array}$ & ha & 421 & 421 & 421 & 446 & 471 & 471 & 471 \\
\hline & percentage & $\%$ & 0.9 & 1.0 & 1.0 & 1.1 & 1.2 & 1.2 & 1.1 \\
\hline \multirow[t]{2}{*}{8} & Oil crop & ha & & & & & & & \\
\hline & percentage & $\%$ & & & & & & & \\
\hline \multirow[t]{2}{*}{9} & grapes & ha & 1250 & 1459 & $\begin{array}{c}1 \\
532\end{array}$ & $\begin{array}{c}1 \\
609\end{array}$ & $\begin{array}{c}1 \\
689\end{array}$ & $\begin{array}{c}1 \\
773\end{array}$ & 1862 \\
\hline & percentage & $\%$ & 2.6 & 3.5 & 3.7 & 3.9 & 4.1 & 4.3 & 4.5 \\
\hline \multirow[t]{2}{*}{10} & $\begin{array}{l}\text { Plots of } \\
\text { citizens }\end{array}$ & ha & 3683 & 3687 & $\begin{array}{c}3 \\
691\end{array}$ & $\begin{array}{c}3 \\
694\end{array}$ & $\begin{array}{c}3 \\
698\end{array}$ & $\begin{array}{c}3 \\
702\end{array}$ & 3705 \\
\hline & percentage & $\%$ & 7.6 & 8.8 & 8.9 & 9.0 & 9.1 & 9.1 & 9.0 \\
\hline \multirow[t]{3}{*}{11} & Farm land & ha & & & & & & & \\
\hline & percentage & $\%$ & & & & & & & \\
\hline & Total area & ha & 48482 & 41875 & $\begin{array}{c}41 \\
642\end{array}$ & $\begin{array}{c}41 \\
247\end{array}$ & $\begin{array}{c}40 \\
766\end{array}$ & $\begin{array}{c}40 \\
775\end{array}$ & $\begin{array}{c}41 \\
099\end{array}$ \\
\hline
\end{tabular}

Opportunities will increase to solve the problem of employment, which is one of the main problems of the region, to ensure abundance and increase the competitiveness of the economy[6]. With this in mind, special attention is paid to the development of this sector in 
the country, since the creation of conditions for the development of small businesses in rural areas can lead to the prosperity of the country. In our opinion, this is due to the following characteristics of small businesses: the ability to quickly adapt to market demand and produce quality products; be able to meet the demand for goods and services required by the population in a relatively short time; that the initial capital is relatively small; the possibility of creating new jobs in the near future and assistance in solving the problem of employment; direct participation of the business owner "entrepreneur" in the performance of the assigned tasks.[7]

Our research shows that in recent years a number of measures have been taken to develop small businesses in the country: the wholesale and retail trade system has been reformed. An effective system of servicing small businesses by infrastructure units is being created. A system is being formed to protect the legal rights and interests of small businesses, as well as to ensure freedom of entrepreneurship.

A simplified and notified procedure for state registration and registration of entrepreneurs has been introduced, and favorable conditions have been created for the free acquisition of material and technical resources by entrepreneurs at exchange auctions. Measures have been taken to simplify the process of mandatory standardization and certification of products of foreign enterprises. a new system of financial support for startup entrepreneurs and other forms of liberalized start-ups, etc. has been introduced.[8,9] To further improve the activities of small enterprises in agriculture, it is necessary to properly organize the effective use of adjacent arable land. If the farmer takes the necessary agrotechnical measures on the land in a timely manner, the yield per hectare will increase. Therefore, the program clearly shows the ways to increase the yield (table 2).

Table 2. Forecast of growing the main crops of the Gallaorol region for 2017-2021.

\begin{tabular}{|c|c|c|c|c|c|c|c|c|c|}
\hline $\mathbf{N o}$ & $\begin{array}{c}\text { Name of } \\
\text { crops }\end{array}$ & $\begin{array}{c}\text { Unit of } \\
\text { measurement }\end{array}$ & $\mathbf{2 0 1 5}$ & $\mathbf{2 0 1 6}$ & $\mathbf{2 0 1 7}$ & $\mathbf{2 0 1 8}$ & $\mathbf{2 0 1 9}$ & $\mathbf{2 0 2 0}$ & $\mathbf{2 0 2 1}$ \\
\hline $\mathbf{1}$ & Cotton & & & & & & & & \\
\hline & square & ha & & & & & & & \\
\hline & harvest & Ton & 0 & 0 & 0 & 0 & 0 & 0 & 0 \\
\hline & yield & c/ha & & & & & & & \\
\hline $\mathbf{2}$ & Cereals & & & & & & & & \\
\hline & square & ha & 39 & 32 & 32 & 31 & 30 & 30 & 30 \\
& harvest & Ton & 31 & 32 & 33 & 33 & 33 & 33 & 33 \\
& yield & c/ha & 12.3 & 9.9 & 9.7 & 9.5 & 9.2 & 9.1 & 9.1 \\
\hline $\mathbf{3}$ & potato & & & & & & & & \\
\hline & square & ha & 427.0 & 283.0 & 297.2 & 312.0 & 327.6 & 344.0 & 361.2 \\
\hline & harvest & Ton & 1941 & 5138 & 9423 & 14 & 19 & 24 & 24 \\
& yield & c/ha & 291.9 & 256.5 & 259.1 & 261.7 & 264.3 & 266.9 & 269.6 \\
\hline $\mathbf{4}$ & vegetables & & & & & & & & \\
\hline & square & ha & 1135 & 1376 & 1 & 1 & 1 & 1 & 1 \\
& hon & 34 & 40 & 49 & 58 & 69 & 77 & 80 \\
\hline & harvest & Ton & 518 & 706 & 390 & 806 & 948 & 163 & 212 \\
\hline & yield & c/ha & 269.1 & 350.0 & 353.5 & 357.0 & 360.6 & 364.2 & 367.9 \\
\hline $\mathbf{5}$ & Melon & & & & & & & & \\
\hline & square & ha & 236 & 218 & 228.9 & 240.3 & 252.4 & 265.0 & 278.2 \\
\hline & harvest & Ton & 1848 & 2198 & 2847 & 3664 & 4539 & 5476 & 5476 \\
\hline & yield & c/ha & 311.7 & 281.4 & 284.2 & 287.1 & 289.9 & 292.8 & 295.8 \\
\hline $\mathbf{6}$ & Fruit & & & & & & & & \\
\hline
\end{tabular}




\begin{tabular}{|c|c|c|c|c|c|c|c|c|c|}
\hline & square & ha & \multirow{2}{*}{1878} & \multirow{2}{*}{1931} & $\begin{array}{c}2 \\
027.6\end{array}$ & $\begin{array}{c}2 \\
128.9\end{array}$ & $\begin{array}{c}2 \\
235.4\end{array}$ & $\begin{array}{c}2 \\
347.1\end{array}$ & $\begin{array}{c}2 \\
464.5\end{array}$ \\
\hline & harvest & Ton & $\begin{array}{c}11 \\
204\end{array}$ & $\begin{array}{c}11 \\
665\end{array}$ & $\begin{array}{c}12 \\
220\end{array}$ & $\begin{array}{c}13 \\
819\end{array}$ & $\begin{array}{c}14 \\
749\end{array}$ & $\begin{array}{c}15 \\
421\end{array}$ & $\begin{array}{c}055 \\
\end{array}$ \\
\hline & yield & c/ha & 124.8 & 175.4 & 177.2 & 178.9 & 180.7 & 182.5 & 184.3 \\
\hline $\mathbf{7}$ & Oil crop & & & & & & & & \\
\hline & square & ha & & & & & & & \\
\hline & harvest & Ton & & & & & & & \\
\hline & yield & c/ha & & & & & & & \\
\hline $\mathbf{8}$ & grapes & & & & & & & & \\
& square & ha & \multirow{2}{*}{1250} & \multirow{2}{*}{1459} & $\begin{array}{c}1 \\
532.0\end{array}$ & $\begin{array}{c}1 \\
608.5\end{array}$ & $\begin{array}{c}1 \\
689.0\end{array}$ & $\begin{array}{c}773.4 \\
8\end{array}$ & 862.1 \\
\hline & harvest & Ton & \multirow{2}{*}{6621} & $\begin{array}{c}15 \\
600\end{array}$ & $\begin{array}{c}17 \\
160\end{array}$ & $\begin{array}{c}18 \\
876\end{array}$ & $\begin{array}{c}21 \\
469\end{array}$ & $\begin{array}{c}23 \\
978\end{array}$ & $\begin{array}{c}26 \\
939\end{array}$ \\
\hline & yield & c/ha & 197.9 & 241.6 & 244.0 & 246.5 & 248.9 & 251.4 & 253.9 \\
\hline
\end{tabular}

Table 3. Projects and Job Creation Program in Gallaorol District.

\begin{tabular}{|c|c|c|c|c|c|c|c|c|c|c|}
\hline \multirow{3}{*}{ № } & \multirow{3}{*}{$\begin{array}{l}\text { Project } \\
\text { direction } \\
\text { name }\end{array}$} & \multicolumn{3}{|c|}{$\begin{array}{l}\text { Number of projects to } \\
\text { be implemented in } \\
\text { 2018-2019 } \\
\text { Total: }\end{array}$} & \multicolumn{6}{|c|}{ Of them: } \\
\hline & & & & & \multicolumn{3}{|l|}{2018} & \multicolumn{3}{|l|}{2019} \\
\hline & & 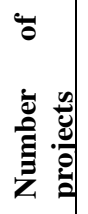 & $\overrightarrow{\tilde{g}}$ & 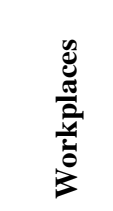 & 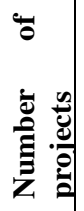 & छे & 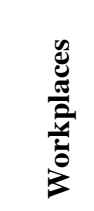 & 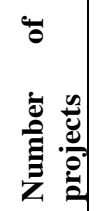 & $\overrightarrow{\tilde{g}}$ & 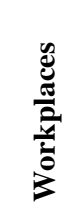 \\
\hline \multicolumn{2}{|c|}{ By district } & 276 & 30962.0 & 4704 & 111 & 10688.6 & 4255 & 165 & 20273.4 & 449 \\
\hline 1 & $\begin{array}{l}\text { Development } \\
\text { of } \\
\text { horticulture }\end{array}$ & 52 & 197.5 & 2578 & 25 & 732.5 & 2496 & 27 & 1241.0 & 82 \\
\hline 2 & $\begin{array}{l}\text { Development } \\
\text { of viticulture }\end{array}$ & 40 & 625.6 & 149 & 19 & 358.9 & 120 & 21 & 266.7 & 29 \\
\hline 3 & $\begin{array}{l}\text { Construction } \\
\text { of new } \\
\text { greenhouses }\end{array}$ & 17 & 1715.0 & 62 & 6 & 540 & 30 & 11 & 1175.0 & 32 \\
\hline 4 & $\begin{array}{l}\text { Livestock } \\
\text { development }\end{array}$ & 55 & 6494.0 & 238 & 29 & 2520.5 & 186 & 26 & 3973.5 & 52 \\
\hline 5 & $\begin{array}{l}\text { Development } \\
\text { of poultry } \\
\text { farming. }\end{array}$ & 10 & 1340.0 & 69 & 4 & 655.0 & 46 & 6 & 685.0 & 23 \\
\hline 6 & $\begin{array}{l}\text { Development } \\
\text { of fisheries }\end{array}$ & 11 & 543.5 & 69 & 4 & 123.5 & 28 & 7 & 420.0 & 41 \\
\hline 7 & $\begin{array}{l}\text { Development } \\
\text { of } \\
\text { beekeeping }\end{array}$ & 17 & 965.0 & 57 & 8 & 520.0 & 34 & 9 & 445.0 & 23 \\
\hline 8 & $\begin{array}{l}\text { Development } \\
\text { of rabbit } \\
\text { breeding }\end{array}$ & 7 & 2303.0 & 124 & 2 & 377.0 & 50 & 5 & 1926.0 & 74 \\
\hline 9 & $\begin{array}{l}\text { Creating } \\
\text { cold storage }\end{array}$ & 10 & 11717.0 & 90 & 4 & 4510.0 & 44 & 6 & 7207.0 & 46 \\
\hline
\end{tabular}




\begin{tabular}{|c|c|c|c|c|c|c|c|c|c|c|}
\hline & facilities & & & & & & & & & \\
\hline 10 & $\begin{array}{l}\text { The } \\
\text { development } \\
\text { of the } \\
\text { vegetables }\end{array}$ & 1 & & 1200 & 1 & & 1200 & & & \\
\hline 11 & $\begin{array}{l}\text { Providing } \\
\text { farmers with } \\
\text { modern } \\
\text { agricultural } \\
\text { machinery }\end{array}$ & 56 & 3285.4 & 68 & 9 & 351.2 & 21 & 47 & 2934.2 & 47 \\
\hline
\end{tabular}

Since independence, our country has paid great attention to the development of the private sector, which has undergone fundamental changes in the organization of small businesses and entrepreneurship, farms, dehkan farms and other enterprises. [10,11]. Therefore, in recent years, the country has taken measures to sharply reduce state participation in the capital of enterprises. Work is currently underway to liberalize the regulatory framework governing the valuation of state property and its subsequent sale as private property. This will solve the problem of job placement. Job creation programs are being developed in the Gallaaral district.[12,13]

According to Table 4, the total number of projects that are planned to be implemented in 2018-2019 is 276, the cost of which is 30962.0 million. In addition, 4704 new jobs will be created.[14] Of the total number of jobs created as a result of development of horticulture will be established 2578 , in the vegetable - 1,200 people, in livestock 238 jobs [15].Cotton is not grown in the Gallaorol district. It is possible to plant all other crops and get high yields. Land, water, and labor resources are not sufficiently organized in just one business environment, namely the right of citizens to own property.

The government creates conditions for expanding the foreign economic activity of economic entities. They are exempt from import duties on the import of technological equipment. This, in turn, will allow us to produce and export competitive products to the world market.

In our opinion, to effectively solve such problems in the development of small businesses, it is necessary to develop and implement strategic programs Of the government of the Republic to support this sector. Such a concept should be based on structural changes that will eliminate imbalances and make better use of the economic potential of the regions.

In our opinion, the main focus of the small business development concept is to support small businesses with economic potential, create favorable conditions for the development of low-income sectors necessary for the industry and the region, stimulate economic structures that act in accordance with the directions and goals of the Republic's socioeconomic policy, establish tax incentives for small enterprises of regional significance, expand the insurance system for leasing services and investment projects, and further expand access to Bank loans for small businesses.

As a result of measures taken in the country to create new jobs, more than 400 thousand jobs were created in 2019 alone. The district has programs aimed at sharply reducing the number of unemployed among the non-working working-age population. Further development of the service sector and small business as the most important factor in ensuring the life of the population and improving the standard of living remains a priority.[16]

\section{Result}


According to Table 3, the total number of projects to be implemented in 2018-2019 is 276, the cost of which is $30,962.0$ million soums, while 4,704 new jobs will be created. Of the total number of jobs created as a result of the development of gardening, 2,578 people will be created, in vegetable growing - 1,200 people, in animal husbandry - 238 jobs. No cotton is grown in the Gallaorol region. There is an opportunity to plant all other crops and get high yields. Land, water and labor resources are insufficiently organized in only one business environment, namely the right of citizens to own property.[17]

The government creates conditions for the expansion of foreign economic activity of economic entities. They are exempted from import duties on the import of technological equipment. This, in turn, will allow the production and export of competitive products to the world market.

In our opinion, in order to effectively solve such problems in the development of small business, it is necessary to develop and implement strategic programs of the Government of the Republic to support this sector. This concept should be based on structural changes that will eliminate imbalances and more effectively use the economic potential of the regions.

In our opinion, the main direction of the concept of small business development is to support small businesses with economic potential, to create favorable conditions for the development of low-profit sectors necessary for the industry and the region to work in accordance with the directions and goals of socio-economic policy. stimulating economic structures, tax incentives for small businesses of regional importance, expanding the insurance system for leasing services and investment projects, as well as further expanding access to bank loans for small businesses with limited financial resources.

As a result of the measures taken in the country to create new jobs, more than 400 thousand jobs were created in 2019 alone. There are programs in the region aimed at a sharp reduction in the number of unemployed among the non-working able-bodied population. Further development of the service sector and small business as the most important factor in ensuring the livelihoods of the population and improving living standards remains a priority task.[18]

3.2. Based on world experience, in our opinion, the most important areas for the formation and development of a small business support system are the formation of a legal environment, institutional changes, the development of business culture, labor, financial, material, One of the main conditions for providing the state with information and other types of resources, necessary for the production process is the direct implementation of its function of the "Main reform". Along with these areas, the main factor influencing the quality of the support policy is public organizations. They can reflect the interests of small businesses and lead to positive changes in government support policies.

- Attracting large segments of the population to the market, addiction, elimination of consumer psychology, entrepreneurship, infection with the "disease" of desire to engage in private business:

- creation of new jobs for employment of those who lost their jobs due to the reconstruction of agriculture; 


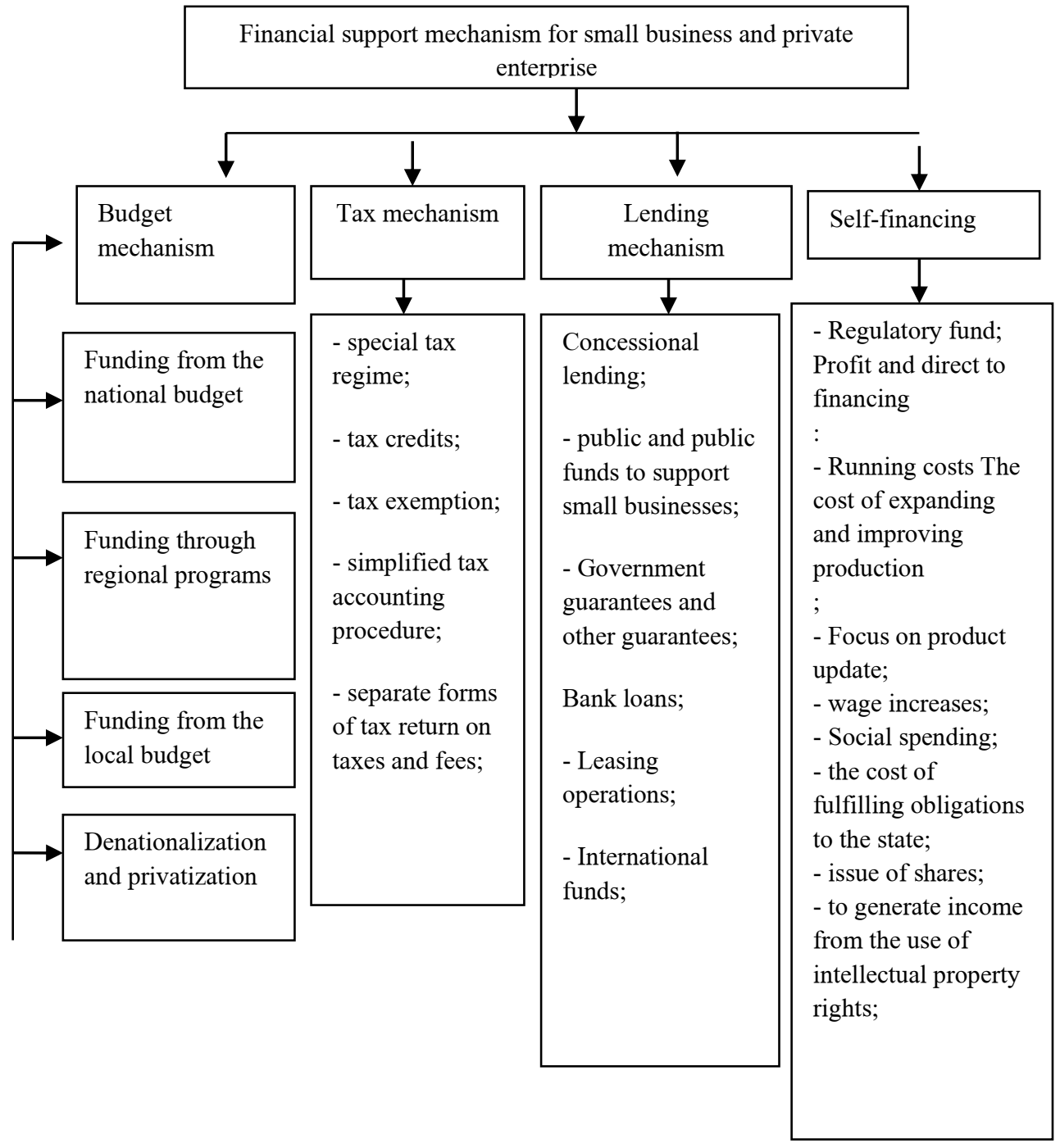

Fig. 1. The mechanism of financial support for small business and private entrepreneurship.

- rapid development of market relations and infrastructure in rural areas, creating conditions for competition;

- a sharp increase in the volume of required services, especially in connection with the Bank's audit activities;

- introduction of small and private enterprises with flexible production, which fill the domestic market with necessary goods and increase export-oriented production in order to increase economic efficiency.

The number of small businesses and entrepreneurship in Uzbekistan in the field of material production, including textiles, deep processing of agricultural products, should be increased. Medium and large enterprises should not only create small businesses that produce goods from waste, but also encourage their growth in other areas, especially in rural areas, through financial assistance. 
This year, the Ministry of Finance and the Ministry of economy are developing and implementing a special mechanism to expand the use of public procurement by small businesses through the allocation of special quotas. Phased implementation is provided.[19]

The Central Bank, together with commercial banks, should continue to work on further improving and expanding the mechanisms for providing loans to small businesses, primarily long-term loans for investment purposes, forming start-up capital, and expanding the volume of micro-loans.

It is necessary to create a fund to finance the preparation of investment project documents together with the Association of Banks of Uzbekistan and commercial banks. This will allow small businesses to reduce the cost of preparing business plans, improve their quality and shorten lending terms. For small businesses, it is necessary to eliminate unnecessary internal procedures when formalizing foreign trade operations, to give additional preferences when it comes to exporting products from the small business sector.

Based on the above, it should be noted that state support for the development of small businesses in the context of modernization and liberalization of the economy is bearing fruit and serves to strengthen their position and place in the national economy.

\section{Conclusions}

Based on the results of the study, the following conclusions and recommendations were prepared for the development of the subjects of the formation of agribusiness in rural areas.

1. Entrepreneurship is a type of agribusiness, which is economic relations that arise in the production of goods and services, based on the management of the use of capital and other economic resources for profit. Small business is the driving force behind the economy. This is a purposeful activity that manifests itself in the behavior of specific people. It is necessary to simplify the organizational basis for organizing entrepreneurial activities, to increase the potential of personnel in the effective use of regulatory documents, organization of work using historical and best practices.

2. The strategic direction of the development of agriculture requires the formation of new economic views and ideas that ensure the sustainable development of production in society, including in agriculture, a radical reform of economic management, a constant search for new management methods and their implementation in everyday life. is done.

3. There are a number of factors influencing the development of small business in the formation of agribusiness in agriculture, based on the division of these factors into four main groups: resource factors, production factors, organizational factors, and political and legal factors. In our opinion, it would be wrong to say that none of these factors is of primary importance, and the other is secondary. However, given the current demand, we consider it appropriate to pay more attention to economic factors.

4. In the context of market relations, business and entrepreneurship are economic categories that represent economic relations between economic entities. Business is the main economic category in relation to entrepreneurship and has a number of characteristics. These include: business participants seeking to make a profit or profit; to this end, they benefit from the interaction of capital and property, the efficient use of capital, a sense of economic risk, the desire for entrepreneurship, initiative, innovation;

The essence of private entrepreneurship is expressed in the following:

- Development of software production of small enterprises based on natural resources of each region will strengthen their economic positions;

- Small business development will strengthen the country's economy;

- Provides the development of small businesses based on free competition;

- Small business development will increase national income; 
Based on the above, the following features of small business can be noted:

- the ability to quickly adapt to market demand and produce quality products,

- be able to meet the demand for goods and services for the needs of the population in a short time

- initial capital is relatively small

- The opportunity to create new jobs in the near future and help solve the problem of employment

- direct participation of the business owner "entrepreneur" in the implementation of the relevant tasks.

5. With the formation of agribusiness in agriculture, small enterprises have become a leading force in the country's economy, filling our markets with the necessary goods and services, the main source of increasing income and welfare, an important factor in solving employment problems. Today, small business is developing not only quantitatively, but also qualitatively, moving from simple production to complex high-tech production focused on the domestic and foreign markets.

6. In the agrarian sector, farms have developed as typical representatives of small businesses. But there are also a number of problems in the system of organizing and managing their activities. To solve the existing problems, it is necessary to increase the efficiency of production in farms, reduce the consumption of natural, material, technical, labor and financial resources per unit of production, stimulate them to use resources efficiently and improve the mechanisms for modernizing production processes.

7. Farms must not only grow crops, but also fill the domestic market with products:

- processing of agricultural products at the level of world market standards and access to foreign markets;

- increase the export potential of farmers and entrepreneurs working in remote areas, provide them with the necessary information, including the development of modern compact equipment and mini-technologies;

- it is necessary to put an end to the existing and unnecessary bureaucracy in the field of standardization and certification of small enterprises and farmers themselves, processed and industrial products, in order to further improve the regulatory framework of their activities;

8. The results of the study show that in the formation of agribusiness in agriculture, small businesses are often characterized by attempts to organize high-tech production. They are determined to occupy high-tech space and create a highly specialized product, minimize production costs by purchasing components from large enterprises, adapt technology to consumer demand to facilitate the production process, and try not to attract external investment. attention required.

9. Attention to macroeconomic and regional trends in the organization of small business in the formation of agribusiness in agriculture gives good results, therefore, the study proposes an organizational and methodological model based on the above trends in the development of small business. The proposed model makes it possible to develop small business and entrepreneurship at the national and regional levels.

Therefore, small business leaders in the regions should pay special attention to the introduction of the latest innovations in science and technology.

10. In the country, economists have carried out a number of studies on the management of support for small businesses in the formation of agribusiness in agriculture, and positive results have been achieved. We recommend the target structure of financial support for small businesses, which is one of the key factors in the development of small businesses, based on the experience of our country and abroad, a mechanism that includes a set of internal and external factors, as well as a number of interrelationships. The financial mechanism for the development of small business and 
entrepreneurship will consist of 4 main components: budgetary mechanism, tax, credit and self-financing mechanisms.

11. Based on the experience of our country and the world, the main directions for the formation and development of support for small businesses in the formation of agribusiness in the agro-industrial complex are the formation of a legal environment, institutional changes, the development of an entrepreneurial culture, labor, financial, material, informational and one of the main conditions of management the supply of other types of resources necessary for the production process is the direct fulfillment by the state of its function of the "Main reform".

\section{References}

1. Law of the Republic of Uzbekistan "On property" ("Justice", T., 1991)

2. Decree of the President of the Republic of Uzbekistan of January 6, 2017 PP-2716 "On additional measures to develop storage and deep processing facilities for fruits and vegetables in 2017-2018"

3. Decree of the President of the Republic of Uzbekistan S.M. Mirziyoyev dated February 7, 2017 No. PF-4947 "On the Strategy of Action for further development of the Republic of Uzbekistan"

4. Decree of the President of the Republic of Uzbekistan of September 15, 2017 No. PP3281 "On measures for the rational placement of crops and the projected volumes of agricultural production in 2018"

5. Decree of the President of the Republic of Uzbekistan of October 9, 2017 "On measures to fundamentally improve the system of protection of the rights and legitimate interests of farmers, dekhkan farms and landowners, the management of agricultural land"

6. Resolution of the Cabinet of Ministers of the Republic of Uzbekistan of January 9, 2019 No. 14 "On additional measures to optimize land and efficient use of agricultural land for farms and other agricultural enterprises." The President's Decree of March 14, 2019 No. PP-4239 "On the development of agricultural cooperation in the field of fruit and vegetable products"

7. Decree of the President of the Republic of Uzbekistan No. PP-3077. OR NGO No. 25, Article 535 (2017)

8. Uzbekistan's Cooperation Act ("Justice", T., 1993)

9. Uzbekistan's Entrepreneurship Act. Laws and decrees of the Republic of Uzbekistan ("Justice", Tashkent, 1992)

10. Uzbekistan's Property Act. Laws and decrees of the Republic of Uzbekistan ("Justice", Tashkent, 1992)

11. "Labour Code" of the Republic of Uzbekistan ("Justice", T., 1996)

12. Decree of the President of the Republic of Uzbekistan No. PF-3226 of May 25, 2017 "On measures to further stimulate exports and competitiveness of domestic products in foreign markets"

13. Decree of the President of the Republic of Uzbekistan on March 29, 2018 No. PF-5388 "On additional measures to accelerate the development of fruit and vegetable production in the Republic of Uzbekistan"

14. Cabinet resolution of January 14, 2018 "On measures to organize more efficient use of farm land and obtain additional income" 
15. A. Maksumxanova, M. Saidova, B. Shafkarov, IOP Conf. Ser.: Earth Environ. Sci. 421, 022004 (2020) https://www.scopus.com

16. M. Saidova, Economy and Finance (Uzbekistan) 9 (2019) https://cyberleninka.ru/article/n/molodyozhnaya-bezrabotitsa-na-rynke-trudauzbekistana-problemy-i-nekotorye-puti-resheniya

17. M. Saidova, Modern Education (Uzbekistan) 1 (2020)

18. M. Saidova, Agriculture and economy 3 (2019)

19. A.Yu. Toshboev, B. Azizkulov, Ways to use resource-saving technologies in the cultivation of agricultural products (Monograph-T.: «MUXR-PRESS», 2017)

20. A.J. Toshboyev, N.M. Mardiyev, I.N. Ziyadullayev, R.B. Azimov, A.M. Zakimov, IOP Conference Series: Materials Science and Engineering. Krasnoyarsk Science and Technology City Hall of the Russian Union of Scientific and Engineering Associations Krasnoyarsk, Russia, 42006 (2020) 